\title{
Refugee From High Tuberculosis Prevalent Area
}

National Cancer Institute

\section{Source}

National Cancer Institute. Refugee From High Tuberculosis Prevalent Area. NCI

Thesaurus. Code C102705.

An individual that has fled a country for their own safety which has a high occurrence of tuberculosis. 